\title{
O Vaticano II na prática da Igreja Particular de Goiás
}

Vatican II in the Church in the Diocese of Goiás-Brazil

Dom Tomás Balduino*

\begin{abstract}
Resumo
Apresenta-se nesse texto as repercussões do Concílio Vaticano II na Igreja particular de Goiás. A fidelidade ao Concílio produziu efetiva participação de todos - presbíteros, religiosas e religiosos, leigos e leigas. Tomando como referências a vivência e experiência de pastor nessa diocese (1967-1998) e diversos estudos, Dom Tomás mostra os aspectos mais relevantes dessa história: as assembléias diocesanas, com participação de leitos (1968); as CEBs e a concretização da opção pelos pobres; as Escolas Bíblicas; a defesa da posse da terra, a Comissão Pastoral da Terra - CPT e o enfrentamento da ditadura militar; a causa indígena; o ecumenismo; o exercício da colegialidade; a articulação dos bispos comprometidos com as CEBs na CNBB; o problema da Visita Apóstólica na diocese; apresenta ainda um balanço de erros e conflitos; e finalmente, relata o Sínodo diocesano (1995) e seus objetivos: 1) Avaliar a situação concreta do povo, seus sofrimentos e suas lutas, para se ter uma visão mais clara da realidade; 2) Julgar à luz da Palavra de Deus;. 3) Desenvolver com mais clareza a missão da nossa Igreja dentro dessa mesma realidade.
\end{abstract}

Palavras-chave: Concílio Vaticano II. Diocese de Goiás-Brasil. Participação. Colegialidade.

\begin{abstract}
Abstrat
This article written by Archbishop Tomás Balduíno presents the impact of Vatican II in the particular Church of Goiás, emphasizing that the loyalty to the Council produced effective participation of priests, religious and lay people. Given his experience as a pastor in this diocese (1967-1998) and several studies, Bishop Thomas shows the most relevant aspects of this story: the diocesan assemblies, with the participation of lay people (1968); the CEBs and realization of the option for the poor; the Bible Schools; the defense of land tenure, the Pastoral Land Commission - CPT and the facing of the military dictatorship; the indigenous cause; ecumenism; the exercise of collegiality; the articulation of the bishops committed to the CEBs in CNBB; the problem of apostolic visit in the diocese. The article also presents a balance of errors and conflicts, and finally reports the diocesan Synod (1995) and its objectives: 1) Evaluate the concrete situation of the people, their sufferings and their struggles to get a clear picture of reality; 2) To make the judgment of reality in light of the word of God; Develop more clearly the mission of our Church in this reality
\end{abstract}

Keywords: Vatican II. Diocese of Goiás-Brazil. Participation. Collegiality.

Artigo publicado no Mutirão (Minga) Temático de Revistas Latino-americanas, organizado pela parceria Koinonia/ASETT (Associação Ecumênica de Teólogos/as do Terceiro Mundo ASETT/EATWOT).

* Bispo emérito da Diocese de Goiás, religioso da Ordem Dominicana, assessor da Comissão Pastoral da Terra - CPT. País de origem: Brasil. E-mail:

1

Horizonte, Belo Horizonte, v. 9, n. 24, p. 1341-1360, dez. 2011 - ISSN: 2175-5841 


\section{Introdução}

Estamos comemorando os 50 anos do Concílio Vaticano II. Fizeram-me o honroso pedido de elaborar umas considerações sobre este grande evento eclesial. Pensei, então, apresentar, de forma resumida, a aventura acontecida na Igreja particular de Goiás, depois que nela se assumiu o compromisso de fidelidade a este Concílio. Foi uma prática que envolveu a participação efetiva de presbíteros, religiosas, leigos e leigas e onde tive o privilégio de atuar como pastor.

Tudo começou nos últimos dias de 1967 e nos primeiros de 1968. A distância de 30 anos do acontecido, a sua complexidade e a riqueza dos comentários sobre o mesmo, me levaram a utilizar alguns dos seguintes escritos a respeito: "Igreja do Evangelho" Eliseu Lopes e Carlos Brandão (texto mimeografado, 180 p.); "Um tempo de Graça, a Caminhada da Diocese de Goiás" Francesco Capponi; "Uma vida a serviço da Humanidade" Vários autores, organizador Ivo Poletto; "Viver a Unidade: Um Projeto de Vida" Marcelo Barros (texto na internet). "Profecia e Diálogo - Caminhada da Diocese de Goiás" Arcângelo Scolaro.

Naquela época respirava-se um clima de otimismo e de expectativa no mundo inteiro. Basta lembrar a amenização da guerra fria, com Jonh Kennedy e o aparecimento de um camponês mais aberto na Rússia, com Nikita Kruscev. Porém o que mais surpreendeu foi o papa João XXIII à frente da Igreja, jovem de espírito nos seus 79 anos, bem humorado e otimista. Um otimismo sobretudo no relacionamento da Igreja com o mundo, visto não mais como maldito mas como o lugar de Deus, lugar para o qual a Igreja precisaria se abrir. Foi diante da magnitude desta perspectiva que o Papa pensou no Concilio ecumênico, como possível resposta adequada às expectativas mundiais que ele chamava de "novos sinais dos tempos".

Se até na Europa havia entusiasmo nesse tempo, imaginem a vibração na sociedade e na Igreja da América Latina. A Conferência episcopal continental acontecida em Medellín viveu um verdadeiro Pentecostes. Os Bispos proclamaram então: 
Não basta, certamente, refletir, conseguir mais clareza e falar. É necessário agir. A hora atual não deixou de ser a hora da "palavra", mas já se tornou, com dramática urgência, a hora da ação. Chegou o momento de inventar com imaginação criadora a ação que cabe realizar e que, principalmente, terá que ser levada a cabo com a audácia do espírito e o equilíbrio de Deus.

Antes de chegar à Diocese de Goiás eu adquirira uma certa prática de coordenação de Igreja no Pós Concílio, com base no Plano Pastoral de Conjunto. Eu era Prelado de Conceição do Araguaia, confiada à Ordem dominicana a serviço de camponeses, além de vários grupos indígenas.

Ao tomar posse da Diocese de Goiás a 17 de dezembro, na homilia convidei o povo "a seguir os caminhos traçados pelo Concílio e a se abrir ao mundo para ser sinal do Reino”. Estávamos nos anos de chumbo da Ditadura militar. Apenas quinze dias depois, já no início de 1968, convidei os padres da Diocese, diocesanos e religiosos, ao todo 16, para uma reunião. Os objetivos eram: primeiro levantar a situação religiosa e social da Diocese, segundo, chegarmos ao acordo de assumir ou não em nossa Igreja de Goiás a renovação proposta pelo Concílio Vaticano II. Assumimos todos colegiada e alegremente este compromisso.

Escreve o Pe. Capponi: "Eu era recém chegado a Goiás, da Itália. Era padre novo e entusiasta do Concílio. Fiquei impressionado com a democracia e o senso de liberdade que havia na presença do bispo: todos tomavam a palavra, ele escutava a todos, e não vestia nem sequer a batina. Nunca tinha visto, até então, um bispo sem hábito, sem a cruz peitoral, sem o anel de esmeralda. Pensei: "Neste ambiente dá para realizar uma Igreja do povo" (p. 24).

\section{Assembléias diocesanas}

No final daquela reunião, depois das providências práticas, nomeação de uma coordenação diocesana, o bispo anunciou sua intenção de convocar uma Assembléia com a participação dos leigos. O primeiro trabalho da Coordenação foi acertar os detalhes da organização desta Assembléia. Estavam convocados todos os padres diocesanos e 
religiosos, todas as religiosas, mais quatro leigos de cada uma das 16 paróquias, um homem e uma mulher, um rapaz e uma moça.

A $1^{\text {a }}$ Assembléia diocesana realizou-se em Ceres de $1^{\circ}$ a 7 de julho de 1968 . Na parte da manhã um assessor expunha o ensinamento do Concílio sobre cada linha da pastoral de conjunto. Na parte da tarde eram trabalhos de grupos e plenário. À noite havia lazer para o pessoal, enquanto a coordenação apurava as propostas e preparava o texto de votação para a manhã seguinte.

Os leigos eram maioria. Havia liberdade, fraternidade e democracia. Todos tinham direito à palavra e o voto de cada leigo ou leiga tinha o mesmo valor que o voto dos padres e do bispo. Ao resultado final da assembléia deu-se o nome de "roteiros". Estes, na data de 25 de julho foram oficialmente publicados e, por decisão do bispo, deveriam ser tidos como Lei Diocesana, a título de experiência até a próxima Assembléia diocesana em julho de 1969.

Não se pense que foi uma Assembléia de transformação da Instituição. Conseguiu, quando muito, modernizá-la, sem tocar na sua estrutura. $\mathrm{Na}$ linha da renovação, o fato mais significativo foi a própria Assembléia em si. Ela tomou o lugar do Sínodo diocesano previsto pelo Direito canônico, com muito maior amplidão, eficácia e freqüência. Abriu possibilidades para a presença de certos elementos de democracia no comando da Diocese. Esta significação aumenta se considerarmos que a Assembléia impôs-se como uma nova instituição assumida também pelas paróquias (cf A Igreja do Evangelho, pág. 29) Foi graças a este instrumento, repetido anualmente, levado a sério em toda a Diocese e cuidadosamente preparado, que foi se concretizando o sonho e compromisso iniciais de renovação, na linha do Vaticano II.

Esta renovação não aconteceu, de súbito, de cima para baixo, na forma de decretos promulgados pelo bispo. Ao contrário, veio lentamente a partir das bases populares mais pobres e mais marginalizadas. Confesso que fui envolvido por este processo e mesmo se não o quisesse, não escaparia dele porque, a certa altura, contagiara todo o corpo da Igreja. Aconteceram alguns fatos surpreendentes na seqüência destas Assembléias: No final da $3^{\mathrm{a}}$ Assembléia, diante da audácia das conclusões a que ela chegara, o bispo fez esta declaração pública: "Se em alguma passagem não estivermos em plena comunhão com a Mãe Igreja e com o Papa, não vacilaremos em modificar nosso passo." 
O grande marco histórico da caminhada da Diocese foi a $5^{\text {a }}$ Assembléia, realizada em julho de 1972. Os delegados leigos não foram mais os eleitos nas paróquias, mas sim os eleitos dos novos grupos da roça e da periferia, que tinham assumido a evangelização a partir da ligação Evangelho-vida. Leigos, portanto, pobres e sofridos, e não preocupados apenas com as estruturas eclesiásticas, mas com a situação do povo. Tivemos como assessor Dom Pedro Casaldáliga, bispo de São Félix, um testemunho de coragem e profecia na defesa de índios e posseiro do Araguaia e, por isso perseguido pelos militares.

Durante aquela Assembléia chegou-nos a notícia do processo de expulsão sumária do padre Francisco Cavazzuti, com 48 horas para deixar o país, crime contra a Segurança nacional. Ele vinha, de fato, aconselhando os pequenos proprietários da região do Rio Vermelho a não venderem suas terras ao governador do Estado, Leonino Caiado, que planejara ali estabelecer a sua grande fazenda. A solidariedade das Igrejas forçou o governo a recuar.

Enquanto isso a Assembléia estava refletindo sobre a opção preferencial pelos pobres, na perspectiva de ser a opção da Diocese. Não foi um parto sem dor. Formaram-se como que dois partidos contrapostos. Os argumentos dos "contra", apoiados por alguns padres, eram: a opção seria discriminação, seria tomar atitude política, enquanto a Igreja está acima da política e lida só com o espiritual, seria "horizontalismo".

A decisão final da Assembléia pelos pobres e marginalizados significou para alguns optar por deixar esta Igreja. Foi sofrido, correram lágrimas, não foi agradável para ninguém. Foi um caminho de cruz, a mesma cruz levada continuamente pelos marginalizados. Eis o resultado do que foi aprovado pela maioria dos participantes desta Assembléia:

"I. Constatações:

1. A atividade paroquial na Diocese é insuficiente para a evangelização das pessoas marginalizadas.

2. A grande maioria da nossa população é formada justamente por estas pessoas marginalizadas.

3. Em face disso a $5^{\mathrm{a}}$ Assembléia faz as seguintes opções: 


\section{II.Opções:}

1. A Diocese, em toda a sua atividade pastoral, decide ter uma atenção preferencial aos marginalizados pela sociedade e pela Igreja.

2. A Diocese encaminhará o seu trabalho na linha de uma eficiente evangelização, a fim de chegar a comunidades formadas por cristãos conscientes e comprometidos na transformação da realidade.

3. 3. Os cristãos da nossa Diocese empenhar-se-ão num testemunho pessoal e comunitário a favor da Verdade e da Justiça. Esta opção se traduzirá em atitudes de conscientização, de promoção e de denúncia."

O Bispo, na carta de apresentação destas opções, comentou: "São poucas as palavras, porém densas de conseqüências". E acrescentou: "Embora passando por outros caminhos, vemos que chegamos à mesma decisão do Concílio que diz: “A missão da Igreja é iluminar o mundo inteiro com a mensagem evangélica”. (GS.,92).

\section{Comunidades Eclesiais de Base}

$\mathrm{Na}$ Diocese não falava em Comunidades Eclesiais de Base (CEBs) O que era conhecido eram os Grupos de Evangelho. Na prática é a mesma coisa. Eles existem desde 1972 e foram a primeira concretização da opção pelos pobres. Tinham uma expectativa: converter não só as pessoas mas também as estruturas injustas. Em muitos desses grupos havia experiências de vida comum: roças comunitárias, mutirões de serviço na roça, fiandeiras, violeiros, artesanato. Os agentes da Diocese ocupavam a maior parte do seu tempo na formação deles, passavam as noites em reunião e oração com eles, principalmente na roça e nas periferias da cidades. E foram se multiplicando. Em Itapuranga formaram mais de 50 grupos de base. Pouco a pouco foram fazendo suas reuniões sozinhos, com autonomia. A gente assistia ao vivo ao milagre da libertação. Obra do Espírito Santo. Pessoas que se consideravam ignorantes, nunca tinham falado em público, se descobriam inspiradas e chamadas a agir no projeto concreto de Deus. Experimentavam uma grande alegria. Não custaram a surgir espontaneamente músicas e poesias do povo, cantando a luta, seus sofrimentos e sua esperança. Surgiram os compositores populares muito solicitados e 
dedicados. Esse clima de inspiração poética invadiu a $8^{\mathrm{a}}$ Asssembléia diocesana, mais celebrada do que discutida. Os leigos, geralmente lavradores, tinham encontrado na música o seu jeito mais apropriado de expressão.

Nossa Igreja entrou no "trem das CEBs". Era como se designavam os encontros nacionais e intereclesiais de comunidades de base, que iam crescendo cada vez mais em número de participantes e de bispos que iam aderindo ao movimento. A afirmação corrente é que as CEBs são "o novo modo de ser Igreja" ou "o melhor modo de ser igreja" segundo D. Aloísio Lorscheider. Por isso nunca houve na Diocese uma organização pastoral das Cebs por se tratar da forma nova de ser Igreja. A influência destas comunidades chegaram até o encontro latino americano de Puebla que declarou: "A difusão das comunidades de base ajudou a Igreja a descobrir a força evangelizadora dos pobres” (Puebla, 910).

\section{Escola bíblica}

Durante esse período, a Igreja de Goiás deu prioridade à Escola bíblica para o povo todo e a organizou pra valer. Na transição de uma Igreja clerical, sacramentalista e santeira para uma Igreja do Evangelho e Povo de Deus compreendemos a Palavra de Deus como sustentáculo e vigor da nossa Caminhadada, além de fonte abundante da vida espiritual. Este Projeto levava consigo o sonho, partilhado por muitos diocesanos, de fazer da Escola bíblica uma referência na nossa Igreja com a mesma força cultural da Missa dominical. Nós nos espelhávamos um pouco na "Escola dominical" dos irmãos protestantes, o segredo da energia bíblica deles. Já havia um estímulo para assumir a Bíblia por parte dos camponeses que, no trabalho da lavoura sentiam o complexo de inferioridade quando viam seus colegas protestantes comentar e manusear a Bíblia com naturalidade.

Desde 79 que, em Belo Horizonte, Fr. Carlos Mesters, partindo de sua extraordinária intuição da leitura popular da Bíblia, reuniu uma notável equipe de biblistas e organizou o Centro de Estudos Bíblicos nacional (CEBI). Tivemos desde o início o privilégio da presença atuante de biblistas como padre Marcelo Barros, padre Felipe Leddet e Eliseu Lopes. Em 1980 a Diocese promoveu a Escola Bíblica para todo o povo e obrigatória para todos os agentes que, feito o curso do CEBI seriam os monitores das 
diversas comunidades e que aí começaram a multiplicar as Escolas. Estas foram a grande ferramenta de ascensão eclesial e até política do povo.

A conquista e a libertação, foram descobertos como o filão principal da história do povo de Deus. A partir desta leitura, os salmos, as falas dos profetas, as palavras de Cristo e o Apocalipse ganharam um sentido novo, animador e inspirados da luta e da caminhada do povo. A fé no Deus libertador, deu coragem às comunidades. A gente percebia de longe o crescer desta clareza. As explicações a respeito da ligação entre o compromisso político e a vida de fé eram cada vez menos complicadas. Os estudos bíblicos significaram uma grande novidade porque se dirigiam aos adultos que não tinham nenhum programa de formação. Mas elas revigoraram também a catequese sempre existente e muito apreciada para crianças e adolescentes. Revigoraram sobretudo a celebração dos sacramentos.

Outras dioceses assumiram também os estudos bíblicos como instrumento da formação eclesial do povo. Padre Marcelo Barros foi convidado por algumas dioceses da Bolívia para introduzir lá a metodologia do CEBI.

\section{A terra}

Na década de 70, $80 \%$ da população da Diocese morava no campo e apenas $20 \%$ nas cidades. Hoje este percentual se inverteu. Além do mais a maioria dos que moravam no campo eram pobres, sem terra ou com pouca terra para viver e trabalhar. Com a presença da Igreja mais identificada com esses pobres e dando-lhes apoio eles não ficaram parados. Tiveram uma caminhada própria. Criaram suas organizações autônomas, não apenas em âmbito regional, mas nacional.

Como isso foi possível no tempo da Ditadura militar? Com efeito, segundo o sociólogo José de Sousa Martins, o golpe militar de 64 foi dado não exclusivamente mas principalmente para esmagar qualquer organização de trabalhadores rurais. Os militares temiam que, através do campo o comunismo internacional entraria no país.

Em face da repressão militar contra os camponeses e que começaram a atingir agentes de pastoral, padres e religiosas que os acompanhavam, os bispos resolveram criar um instrumento de apoio aos trabalhadores rurais e aos agentes de pastoral. Assim nasceu em 1975 a Comissão pastoral da terra (CPT). Mas desde 71 a Diocese vinha ajudando os 
trabalhadores a se organizar. O segredo da CPT, esta pastoral de fronteira, está na inspiração vinda da Conferência de Medellín, onde se fez a opção preferencial pelos pobres, assumidos não mais como objetos da nossa ação caritativa, mas como sujeitos de sua caminhada de luta. Sujeitos autores e destinatários de sua própria história.

Para que essa perspectiva se tornasse viável e não fosse barrada pelas forças de segurança nacional, os camponeses descobriram o guarda-chuva da Igreja. De fato, na minha casa, por exemplo, no Centro de formação diocesano, é que os grupos de trabalhadores rurais começaram a se reunir e se organizar. Trabalhavam seguidamente, com assessores que eles mesmo escolhiam, no estudo da realidade e na criação dos seus instrumentos de luta de forma inteiramente autônoma. Não estavam entrando para uma confraria rural da Igreja, como aconteceu no passado. Eram eles os protagonistas de um caminho novo.

Outro apoio estratégico que estes camponeses procuraram foi o Sindicato dos trabalhadores rurais. Entraram, então, para os sindicatos existentes em todos os municípios. Viram, porém, que era um instrumento inteiramente dominado pelos interesses dos latifundiários. O presidente do sindicato de Goiás era um latifundiário. Este organismo, controlado pela Ditadura, mantinham serviços assistenciais, dentista, aposentadoria, lazer, etc. A solução, encontrada pelos trabalhadores veio logo na criação da oposição sindical. Aí se congregaram e caminharam corajosamente. Pouco a pouco se fortaleceram e até ocuparam a direção de alguns sindicatos. O sindicato de Itaberaí chegou a sofrer intervenção do Estado. Mas a Diocese deu um forte apoio aos sindicatos que se tornaram assunto debatido nas Assembléias diocesanas. Veja-se a declaração da $9^{a}$ Assembléia: "Como muitos de nós estamos nos sindicatos e todos reconhecemos o valor do sindicalismo, convém estudar a situação dos sindicatos existentes assim como dos que precisam ser fundados. Procurar todos os meios para que o sindicato seja um verdadeiro instrumento de conscientização e defesa dos trabalhadores, aproveitando as possibilidades que a lei oferece", (art.VIII). Lutas importantes se travaram. Surgiram líderes que, inspirados e preparados nas reuniões de grupos do Evangelho e nos treinamentos, souberam realmente ficar do lado do interesse da classe.

A Diocese forneceu um bom número de líderes ao movimento sindical e ao futuro movimento político da sociedade. Dos grupos de Evangelho, eles passaram a viver a missão 
de leigos dentro das estruturas da sociedade sem a mesma convivência anterior com na comunidade eclesial. Não foi fácil entender e aceitar esta nova situação. Tornou-se, entretanto um caminho novo.

O futuro, porém dos trabalhadores nem estava nos sindicatos, mas em suas organizações próprias e independentes. Estas vieram à tona com a queda paulatina da Ditadura. Os Sem-terra tornaram-se uma força nacional muito atuante e respeitada.

A CPT, sendo, por fundação, uma pastoral de apoio aos camponeses, foi sendo cada vez mais solicitada a realizar sua missão própria no universo do homem e da mulher da terra. Vem alimentado a espiritualidade e a mística da luta pela terra e na terra pela assessoria bíblica e teológica e pela organização das Romarias da terra, um de seus melhores frutos. Vem oferecendo, quando solicitada, apoio técnico agrícola e apoio jurídico combatendo a praga da impunidade dos crimes dos latifundiários contra os camponeses.

Com isso vários dos seus agentes foram assassinados e outros permanentemente ameaçados de morte. Na Diocese de Goiás houve o assassinato de três sindicalistas. E o Padre Francisco Cavazzuti ficou definitivamente cego por um tiro de cartucheira encomendado por fazendeiros.

A CPT tem contribuído na nova conceituação e reivindicação da Reforma Agrária, incluindo a territorialidade. Trata-se de uma expectativa de todo o povo da terra e de suas organizações, envolvendo não só os assentados do Incra, mas também os extrativistas, os seringueiros, ribeirinhos, quilombolas, quebradeiras de coco, até os povos indígenas, exemplos de comunhão mística com a Mãe Terra. Esta expectativa vem sendo, infelizmente, frustrada pelas políticas públicas. O que tem recebido apoio total e pesados financiamentos por parte do governo é o agro-negócio que está implantando extensões imensas da monocultura da soja, do eucalipto e sobretudo da cana e destruindo os biomas da Caatinga, do Cerrado da Amazônia e do Pantanal. A CPT com a publicação anual dos Cadernos de conflitos, vem cumprindo a missão profética de ser a voz dos sem voz e sem vez. É uma forma de sensibilizar a opinião pública a respeito de crimes, inclusive de trabalho escravo cometidos por grandes empresários do campo e que acontecem no esconderijo distante das florestas. È todo um trabalho de documentação e registro a partir das próprias vítimas, das testemunhas, das publicações jornalísticas, dos processos etc. que são organizados comentados e vem sendo publicados desde 25 anos. Toda essa atividade 
pastoral samaritana da CPT visa o fortalecimento do protagonismo dos camponeses e camponesas. Eles são os verdadeiros agentes da mudança. O que convém, pois, é que eles cresçam e nós diminuamos.

\section{A causa indígena}

Convém fazer referência aos povos indígenas como preocupação e compromisso da Diocese. Isso se deu pelo fato do envolvimento do Bispo com o Conselho Indigenista Missionário (CIMI), tendo participado de sua fundação em 1973, por iniciativa da CNBB, e eleito para sua presidência. Alguns agentes de pastoral da Diocese se ofereceram então para dar assessoria a esta pastoral.

A fundação do CIMI não aconteceu de uma hora para outra. O setor de pastoral social da $\mathrm{CNBB}$, sob a coordenação do Padre Lourenço Sonsbeek e atento à lamentável situação dos Povos indígenas, à insuficiente resposta das missões indigenistas das diversas Prelazias da Amazônia e em face às novas propostas do Vaticano II e sobretudo da Conferência de Medellín, iniciou um longo processo de seminários e encontros com os missionários para estudar a questão e propor alguma solução viável. Uma delas consistia na criação de uma pastoral indigenista nacional, o que resultou, felizmente na criação do CIMI. o atual modelo de missão indigenista levada por diversas prelazias da Amazônia confrontando-os com as novas exigências conciliares.

lguns agentes de pastoral da Diocese, entusiasmados com o aparecimento desta pastoral, se ofereceram para o trabalho de assessoria e foram aceitos. Consistia em ajudar nos encontros e seminários em vários pontos do país e, também, nas chamadas Assembléias de chefes indígenas de diversas tribos. Coerente com a opção de Medellín de respeitar nos índios a sua condição de sujeito com autonomia e deles mesmos irem assumindo os instrumentos de sua libertação, um dons conselheiros do CIMI propôs um novo tipo de serviço aos povos indígenas: as Assembléias de chefes. As missões ofereceriam o espaço e a infra-estrutura e convidaria os índios. A Aeronáutica poderia, eventualmente, colaborar no transporte aéreo dos índios, em razão das grandes distâncias.

As Assembléias aconteceram assumidas imediatamente pelos índios. Foi para nós do CIMI como o "ovo de Colombo". Essas Assembléias que começavam, em geral, num 
clima de muita tensão porque colocava face a face representantes de tribos até então inimigas entre si, avançavam e concluíam da maneira mais surpreendente. Fazia parte da metodologia deixar uma parte da Assembléia aos índios, o tempo que quisessem, para o encontro reservado só a eles, sem a presença de missionário, nem de jornalista nem de antropólogo. Chamava a nossa atenção o cuidado da aldeia anfitriã de acolher nobremente o convidados. Em alguns lugares tiveram o cuidado de construir, para a Assembléia, um grande tapirí de palha, em lugar silencioso, distante do reboliço da aldeia. Na aldeia Sururu, afluente do Tapajós, o chefe Mundurucu recebeu o grupo de visitantes, cerca de uma centena, com o seguinte discurso: "Meus amigos, em outros tempos, se nos encontrássemos a essa distância de uns com os outros, como neste lugar, sabíamos o desastre que aconteceria. Hoje, porém, estamos aqui reunidos e unidos, porque, como índios, reconhecemos que estamos todos dentro da mesma canoa furada". Toda Assembléia começava, naturalmente, pela apresentação dos presentes. Chamava nossa atenção o tempo que gastavam, em geral um dia e uma noite, para se revelarem ao mesmo que a realidade da sua tribo.

As Assembléias quase sempre chegavam, no final, com uma certeza e três decisões: A certeza é que os inimigos dos índios não eram os outro índios. A primeira decisão era a necessidade de recuperação de suas culturas, como a força interior indispensável à sobrevivência. A segunda era começar logo a luta pela recuperação das próprias terras. Finalmente a importância de levar todo este processo com autonomia e autodeterminação. Um chefe dizia: "Na grande precisão procurar ainda o padre. Nos mais, nós mesmos".

A Diocese de Goiás sediou uma dessas assembléias em que os índios queriam discutir a proposta do governo Geisel de "emancipação" dos Povos indígenas do Brasil. A "falsa emancipação" como diziam os índios.

O certo é que nós do CIMI, a Igreja missionária e nós da Igreja de Goiás muito aprendemos com este serviço que prestamos. Os colegas diziam: "Fomos evangelizados pelos índios". 


\section{Erros e conflitos}

Não tardaram a aparecer tensões no seio da Igreja provocadas por radicalismo, falta de atenção e de sensibilidade. A $7^{\text {a }}$ Assembléia, outubro de 1974, afirma: "Para que as festas sejam motivo de alegria e de encontro, numa linha de evangelização, suprima-se, aos poucos, tudo o que aliena, alimenta o poder do dinheiro ou a superstição, fazendo com que o povo seja conscientizado para celebrá-las de acordo com o Evangelho". Mas nem todos viam as coisas com este equilíbrio votado pela maioria daquele colegiado. Chegou-se a alimentar um certo desprezo por algumas formas da religiosidade popular, os terços, as devoções e combatê-las. Tentou-se mudar o jeito das festas de padroeiro, o próprio batismo. A tentativa era de ter só batismo de adultos. Foi discutido em Assembléia e na votação a maioria manteve a forma tradicional. Tentou-se também tirar do povo a procura exagerada do padre e da missa para que despertasse para a valorização da Palavra de Deus, da comunidade, das reuniões do Evangelho e das celebrações com animadores leigos.

Na Diocese se reconheceu que houve erros na caminhada e nem toda a Igreja diocesana andou uniformemente, Houve paróquias onde a posição foi realmente mais radical gerando conflitos, em geral com a classe dominante. Não foi fácil administrar as mudanças. A ruptura provocou conflitos. Uma das comunidades onde o conflito cresceu foi a própria sede da Diocese, a Cidade de Goiás, por motivo da Semana santa que lá segue a tradição mais antiga proveniente da Península Ibérica. Além do mais a organização das celebrações estavam nas mãos de uma associação ligada à elite local e que, com antecedência, se armou de todos os modos contra a Coordenação diocesana propalando junto ao povo que se estava planejando a supressão da celebração dos ritos tradicionais. $\mathrm{O}$ Bispo teve que tomar a palavra para esclarecer o povo sobre qual era a proposta da Coordenação diocesana. Tratava-se simplesmente de introduzir a evangelização em toda sua plenitude, porém respeitando aquelas cerimônia antigas, não as suprimindo, mas tirando partido das mesmas. Enquanto isso ia ganhando corpo e aceitação da comunidade a introdução das novidades da renovação litúrgica dando-lhes uma inspiração e um caráter bem populares. A Semana Santa, que na forma tradicional terminava praticamente com a procissão de enterro do Senhor Morto, foi readquirindo seu primitivo caráter pascal. Por exemplo, de ano para ano ia crescendo o número de pessoas que, no domingo de Páscoa, se 
reuniam às 4 da manhã em torno de uma grande fogueira na praça da Igreja, para dar início à celebração a Vigília Pascal.

\section{Ecumenismo}

Desde a $1^{\mathrm{a}}$ Assembléia diocesana foi assumido o Ecumenismo integrado à pastoral diocesana. Assim está expresso no Roteiro: 1.Haja na Diocese uma comissão ecumênica e nas paróquias uma equipe de ecumenismo para realizar o trabalho de aproximação com os irmãos evangélicos, para a oração em comum, a ação social e para executar as tarefas sugeridas pelo Diretório Ecumênico. Foi definido o seguinte para o contacto com os protestantes: $1^{\circ} \mathrm{Em}$ nossos encontros comuns destacar os pontos em que temos acordo e não os pontos em que temos discordância. $2^{\circ}$ Nos nossos encontros para estudos ecumênicos é necessários nos colocarmos em pé de igualdade, sem pretensão à coordenação ou ao comando. $3^{\circ}$ Ao convidá-los para nossas celebrações, tenhamos presente que possamos atender seus convites também.

Não foi fácil a entrada do ecumenismo em nossa Igreja diocesana. Nas Assembléia ele foi se eclipsando de vagarinho de ano para ano. Demorou para que as comunidades camponesas entendessem a proposta. A população protestante na Diocese é mais ligada à Igreja pentecostal. Não há os chamados protestantes históricos. Cresceu, entretanto, um relacionamento social na base, em virtude da luta conjunta pela terra e na terra. Era chamado o "ecumenismo de base".

O importante é que na Diocese tivemos a bênção da instalação do Mosteiro beneditino da Anunciação. Seus monges vieram do Paraná com o objetivo de ser uma presença monástica em uma Igreja local inserida no meio do povo e comprometida com a caminhada de libertação. A vocação desta comunidade sempre foi ecumênica. Aos domingos à noite os irmãos iam, dois a dois, visitar um templo evangélico da cidade. $\mathrm{O}$ mosteiro era uma referência de acolhida amiga para pastores e fiéis destas Igrejas, assim como era para grupos de devoção católica popular para os lavradores. A ampliação da perspectiva ecumênica (inter-eclesial, ou seja, entre igrejas cristãs) para a macroecumênica, inter-cultural e inter-religiosa) se desenvolveu a partir dos anos 90. O próprio termo "macro-ecumenismo" e a definição de sua linha pastoral foram oficializados no $1^{\circ}$ 
Encontro Continental da Assembléia do Povo de Deus (APD), reunida em Quito (setembro de 1992) Aquele encontro se realizou como reação à comemorações oficiais e triunfalistas do quinto centenário da colonização da América.

No mosteiro da Anunciação, nas segundas-feiras, na oração litúrgica do meio-dia cantavam-se mantras budistas e hindus e liam-se textos das escrituras sagradas de uma religião oriental. Nas terças-feiras cantava-se em Yorubá uma invocação ao Espírito que é comum no Candoblé Ketu. Nas quintas fazia-se memória das espiritualidades indígenas. A sexta-feira, dia santo muçulmano era consagrado ao Islã, o sábado ao Judaísmo e o domingo à unidade entre as Igrejas cristãs.

O mosteiro foi, durante vários anos, o local da Assembléia do Povo de Deus no processo macro-ecumênico,A experiência deste mosteiro, fermento em toda a Diocese, foi viver a ecumenicidade como dimensão de fé e de espiritualidade no dia a dia da vida, como aprendizado permanente, como formação de sensibilidade e aí, sim, poder ser referência de diálogo inter-religioso e inter-cultural.

\section{Colegialidade}

O que distingue logo a Igreja da renovação da Igreja da tradição é a colegialidade. A primeira reproduz o modelo piramidal que vem da Santa Sé, passa pelos bispos, cada um cumulando individualmente os poderes de ordem e jurisdição, incluindo o legislativo, o judiciário e o executivo. Passa finalmente às paróquias onde tudo está centralizado na pessoa do pároco. A Igreja da renovação se inspira, pelo contrário, nas comunidades eclesiais de base com seu modelo circular, congregando fraternalmente os participantes, todos com direito à palavra e direito a decidir comunitariamente. Outra característica dessas comunidades é a sua inserção na realidade e não apenas nas coisas internas da Igreja.

As Assembléias diocesanas, ponto de partida da caminhada da nossa Igreja de Goiás inspiraram todas as estruturas que foram se criando: Equipes, Coordenações, Comissões, Assessorias, Reuniões, etc. As paróquias durante um certo tempo se mantiveram no esquema antigo. Pouco a pouco, entretanto, elas foram se abrindo, sobretudo a partir dos exemplos de párocos que estavam ao mesmo tempo na função de coordenação e assessoria. Tomemos o exemplo da paróquia de Itaberaí. Ao dar posse ao responsável pela Igreja 
paroquial, o Bispo apresentou à comunidade não mais um único presbítero, mas três responsáveis com os mesmos poderes, a saber, além do presbítero, uma moça, e um padre casado. O povo recebeu a mudança tranqüilamente. A reação veio de um promotor público, questionando a legitimidade dos dois outros responsáveis. Veio logo a resposta do Bispo argumentando com o código do Direito Canônico que permite esta composição plural desde que o coordenador seja um presbítero. As outras paróquias foram entrando neste esquema. Não foi fácil. Caminhava melhor quando o padre era aberto e assumia esta nova estrutura e estimulava sua eficácia e sua aceitação na comunidade. De qualquer forma foi um aprendizado para cada um dos membros daquelas equipes, um aprendizado para toda a Diocese.

\section{Visita apostólica}

A Visita apostólica é o instrumento de que a Santa Sé dispõe, de intervenção direta na Diocese, por algum motivo grave relativo à disciplina, à moral ou à doutrina da fé. Sendo Núncio apostólico Dom Baggio ele articulou a Visita apostólica à Diocese de Goiás e à Prelazia de São Félix do Araguaia. A primeira tentativa de intervenção na Diocese teve origem no fato seguinte: Dom Hélio Campos, Bispo de Viana, no Maranhão, e que fizera na sua Igreja um belíssimo trabalho de renovação na linha do Vaticano II, estava internado num hospital de Fortaleza em estado grave. Antes porém que ele morresse foi nomeado para Viana um bispo como Administrador apostólico. Em face disso D. Tomás escreveu uma carta de protesto ao Núncio. Como resposta D. Baggio acenou com a possibilidade do envio de um "visitador apostólico" para informar-se do que ocorria na Diocese. Esse assunto ficou em suspense durante um tempo. Finalmente o mesmo Dom Baggio enviou Dom José Freire Falcão, Arcebispo de Brasília para realizar este trabalho. O motivo alegado desta vez foi a acusação lançada, por Dom Sigaud, arcebispo de Diamantina, contra mim e contra Dom Pedro Casaldáliga de sermos comunistas. O interventor foi hóspede meu. Deixei-o inteiramente livre para verificar o que quisesse, falar com as pessoas, reunir as comunidades, convocar o povo. Antes de vir a Goiás, Dom Falcão atendeu, em Goiânia, o Bispo de Rubiataba, Dom Roriz, para uma conversa em particular. Na visitou à Prelazia de São Félix foi igualmente bem acolhido, por Dom Pedro, na sua casa de paredes sem 
reboco, de telhado de brasilit, sem forro, naquele ambiente religioso de pobreza, de profecia e de paz

Depois desta visita encontrando-me com Dom Pedro resolvemos escrever uma carta conjunta ao Papa Paulo VI procurando saber o que estava mesmo por trás daquela visita. Confiamos a carta a Dom Paulo Evaristo Arns, de viagem para Roma, para entregá-la nas mãos do Papa. Dom Paulo teve um atrapalho em Roma e entregou a carta a uma terceira pessoa com todas as recomendações. Como nunca tivemos resposta chegamos à conclusão que o Papa nunca recebera aquela correspondência. Teria ele sabido daquela visita? Mais tarde me encontrei com o Cardeal Baggio, em Roma, já na condição de Prefeito para a Congregação dos bispos. Cobrei dele o que teria resultado da Visita. Respondeu-me, então, que a coisa não avançou porque o Papa falecera.

\section{O Grupo informal de bispos}

Nossa experiência de Igreja em Goiás, como é sabido, não foi a única no Brasil, nem no Continente latino-americano. Pelas visitas que tive a chance de fazer a diversas Igrejas, do Brasil e de outros paises da América latina dou meu testemunho que a renovação conciliar se deu em várias Igrejas muitas das quais poderiam servir de exemplo para nossa Igreja de Goiás.

Muitas destas Igrejas viveram as mesmas tensões que a nossa, às vezes com pressões internas e externas, vindas do mundo eclesiástico e da sociedade civil ou militar. Eis porque o Grupo Informal de Bispos se tornou nosso oásis de solidariedade e de paz. Trata-se de um encontro anual de Bispos católicos e protestantes do Brasil e da América latina. Seu objetivo foi avançar mais livremente na visão da conjuntura eclesial e social, na busca de soluções adequadas e assim contribuir eficazmente com a Conferência episcopal A origem deste grupo tornou-se muito conhecida com aquela reunião convocada em Riobamba por Dom Leônidas Proaño e onde os participantes, em número de 30, foram presos pela Ditadura militar do Equador, com a disfarçada conivência do Núncio apostólico.

No Brasil começamos a nos reunir durante a Ditadura militar. Havia um clima difícil na Assembléia da CNBB, cuja direção não queria nenhum choque com o comando 
militar. O Grupo informal não se colocou contra a CNBB, mas procurou levar a esta sua colaboração realizando, com liberdade profética, o que a Conferência não conseguia. Ele contou, desde o seu início, com a presença de pastores como D. Hélder Câmara, D. Paulo Evaristo Arns, D, Fernando Gomes dos Santos, D. Pedro Casaldáliga. D. Fragoso, D. José Maria Pires, D. Valdir Calheiros e tantos outros. Como forma de apoio ao povo da terra, aos operários urbanos e aos índios, e aos agentes de pastoral foram lançados escritos assumidos por vários bispos e superiores maiores. Houve perseguições e prisões por causa destes textos. O próprio Grupo tinha que se reunir à sombra das Assembléias da CNBB, porque já se sentia acompanhado pelos órgãos de segurança. Hoje o Grupo continua firme, com o mesmo caráter ecumênico e latino-americano, atuando com leveza e agilidade, embora dentro de uma conjuntura eclesiástica que nem sempre vê com bons olhos este tipo de encontro continental e ecumênico

\section{O Sínodo diocesano}

Era o ano 1994, ano marcado para nossa XVI Assembléia diocesana. Aconteceu, porém, que só se lembrou da Assembléia no final do ano, quando ela já devia ter sido realizada. Foi então que o Bispo, que já vinha amadurecendo a coisa, fez a proposta à Diocese de um Sínodo diocesano. O que se buscava era entender o que estava acontecendo em toda nossa Igreja, na sociedade brasileira e na Igreja em geral. Era um caminho para redefinir o rosto e o coração da nossa Diocese. "Igreja, que dizes tu de ti mesma?" Passaríamos três anos na realização do Sínodo e de fato passamos. Foi convocado oficialmente por ocasião da quaresma de 1995. Na carta de convocação foram formulados os seguintes objetivos:

1. Avaliar a situação concreta do povo, seus sofrimentos e suas lutas, para se ter uma visão mais clara da realidade.

2. Julgar à luz da Palavra de Deus.

3. Desenvolver com mais clareza a missão da nossa Igreja dentro dessa mesma realidade.

O tema em destaque eram os excluídos, tema da Campanha da Fraternidade daquele ano. O povo foi, então, convocado para um "grande mutirão" tendo como opção nos deixar guiar pelo Espírito Santo "para a missão do Reino de Deus nesta hora obscura, confusa, 
violenta, hora em que muitas vezes nos sentimos sem coragem, desanimados, sem força até mesmo para realizar a comunhão e a solidariedade".

No lema do Sínodo estava presente o anseio evangélico de servir os excluídos: "Convidar os pobres, os aleijados, o cegos e os mancos para o banquete" (cf Lc 14,21). Penetrando na vida de nossas comunidades se vê que o povo vive a luta não com tristeza, mas com alegria. Hoje se vêem ainda muitas flores brotando no deserto, muitos sinais do Reino no meio do povo. Sente-se muita firmeza e disposição, mesmo no meio de contradições.

Um acontecimento iluminou todo o Sínodo. Foi a comemoração dos dez anos de atentado do Padre Cavazzuti e que foi chamada "a Marcha dos 5 mil". Foi a 27 de agosto de 97. Partiu de Mossâmedes, a paróquia dele e caminhou, por seis quilômetro até o local do atentado, onde se celebrou a eucaristia. O padre Francisco quis ir à frente, com os braços abertos, em cruz. Eis as palavras que ele pronunciou: "Hoje sei por que não morri, porque o Senhor me conservou a vida! Ele quis que eu fosse um crucificado vivo! Olhem no meu corpo velho e cansado, no meu rosto cego, a imagem de milhões de crucificados vivos! Vejam o que acontece àqueles que têm a coragem de reivindicar o direito dos excluídos! Vejam como Jesus continua a ser crucificado em todos os oprimidos e naqueles que se oferecem para a sua redenção!”.

Ocupando todo o asfalto, formamos uma fila de mais de um quilômetro. Foi um espetáculo maravilhoso na hora do pôr do sol, quando a Serra Dourada, em nossa frente, ficou realmente dourada sob os últimos raios de sol. Voltando ao Sínodo tomo a liberdade de transcrever a parte final da carta de Dom Tomás apresentando o texto da última etapa do Sínodo:

Nesta última etapa, nos propusemos o tema: Igreja de Goiás, que dizes tu de ti
mesma? Foi um momento de plenitude celebrativa, enriquecida com a presença
profética dos violeiros-cantadores Tiãozinho de Itaguari e Manelão de Conceição
do Araguaia. O Sínodo revelou a maturidade da nossa Igreja que teve coragem de
olhar com realismo sobre suas falhas e ao mesmo tempo manteve a esperança de
se organizar melhor internamente como forma de testemunhar evangelicamente o
Senhor Jesus nos dias de hoje. Em segundo lugar, uma palavra sobre a sucessão
do Bispo. Nas conclusões da $1^{\mathrm{a}}$ etapa do Sínodo em 95 , no no 2.15 do documento
final está dito o seguinte: "Que a Diocese assuma, de forma participativa, a
sucessão episcopal de D. Tomás, que acontecerá a partir de 98 , buscando na
reflexão, na oração, os caminhos para a continuidade da caminhada realizada
até agora". A minha parte, embora limitada, eu já a estou cumprindo. Consiste
em apresentar uma proposta de nomes à Nunciatura. Só que esta exige total
sigilo. Portanto eu peço a confiança dos irmãos e irmãs. Enquanto isso vou 
ficando à disposição, de todo coração. A parte pedida pelo Sínodo aos diocesanos, a ação, eu a vejo sobretudo na exigência de união de todos em torno da nossa caminhada e, mais ainda, no fortalecimento do laicato, desde as Comunidades Eclesiais de Base até os Conselhos de Leigos, conforme proposta deste Sínodo. É tempo de Advento, é tempo de Vigília do Jubileu, é tempo de renovação de cada um de nós e de toda a nossa Igreja de Goiás.

Vem, Senhor Jesus, vem! Amém.

Dom Tomás Balduino

Bispo de Goiás.

\section{REFERÊNCIAS}

LOPES, Eliseu; BRANDÃO, Carlos. Igreja do Evangelho. Mimeo, (197-], 180p.

CAPPONI, Francesco. Um tempo de Graça: a Caminhada da Diocese de Goiás. [s.1.]: [s.n.], [s.d.].

POLETO, Ivo (Org.). Uma vida a serviço da Humanidade: diálogos com Dom Tomás Balduino. São Paulo: Loyola, 2002.

BARROS, Marcelo. Viver a Unidade: um Projeto de Vida. Marcelo Barros.

SCOLARO, Arcângelo. Profecia e Diálogo: análise sociocultural da dicocese de Goiás 1967-1998. (2001). 236f. Dissertação (Mestrado). Departamento de Filosofia e Teologia, Universidade Católica de Goiás. 